Cite this: Mater. Chem. Front., 2018, 2, 700

Received 5th January 2018,

Accepted 24th January 2018

DOI: $10.1039 / c 8 q m 00004 b$

rsc.li/frontiers-materials

\title{
A carbon-oxygen-bridged hexacyclic ladder-type building block for low-bandgap nonfullerene acceptors $\dagger$
}

\author{
Ting Li, $\neq^{\mathrm{ab}}$ Honghong Zhang, $\ddagger^{\mathrm{b}}$ Zuo Xiao, (D) ${ }^{\mathrm{b}}$ Jeromy J. Rech, (D) ${ }^{\mathrm{c}}$ Helin Niu, ${ }^{\star a}$ \\ Wei You (iD *c and Liming Ding (iD *b
}

\begin{abstract}
A hexacyclic carbon-oxygen-bridged ladder-type unit, $\mathrm{CO}_{i} 6$, was developed. Three nonfullerene acceptors $\left(\mathrm{CO}_{i} 6 \mathrm{IC}, \mathrm{CO}_{i} 6 \mathrm{FIC}\right.$ and $\left.\mathrm{CO}_{i} 6 \mathrm{DFIC}\right)$ based on $\mathrm{CO}_{i} 6$ were prepared. They present low optical bandgaps of 1.31-1.37 eV and strong absorbance in the near-infrared region. A 9.12\% power conversion efficiency was achieved from the solar cells based on $\mathrm{CO}_{\mathrm{i}} 6 \mathrm{FIC}$ and a wide-bandgap copolymer donor (FTAZ).
\end{abstract}

Recently, acceptor-donor-acceptor (A-D-A) small molecules have emerged as efficient acceptor materials for organic solar cells (OSCs). ${ }^{1}$ These molecules generally consist of a laddertype electron-donating core unit and two strong electronwithdrawing end units. ${ }^{2}$ The merits of A-D-A acceptors are as follows: (1) tunable energy levels and good electron mobility to match donor materials; (2) strong visible and near-infrared (NIR) absorption to generate more excitons; (3) out-of-plane side chains to avoid over aggregation and to realize optimal morphology. ${ }^{3}$ Over $14 \%$ power conversion efficiency (PCE) was first reported by Ding et al. ${ }^{4}$

Molecular engineering via tailoring the structures of core units, end units and the side chains is the key toward highperformance A-D-A nonfullerene acceptors. ${ }^{5}$ Recently, our group has developed novel carbon-oxygen-bridged (CO-bridged) laddertype core units for making efficient A-D-A acceptors. ${ }^{6}$ Compared with carbon-bridged (C-bridged) units, CO-bridged units show enhanced electron-donating capability and planarity. CO-Bridged A-D-A acceptors present narrower bandgaps, stronger lightharvesting capability, higher electron mobility and better photovoltaic performance. ${ }^{6}$ Low-bandgap nonfullerene materials have attracted great attention due to their potential application

\footnotetext{
${ }^{a}$ School of Chemistry \& Chemical Engineering, Anhui Province Key Laboratory of Chemistry for Inorganic/Organic Hybrid Functionalized Materials, Anhui University, Hefei 230601, China. E-mail: niuhelin@ahu.edu.cn

${ }^{b}$ Center for Excellence in Nanoscience (CAS), Key Laboratory of Nanosystem and Hierarchical Fabrication (CAS), National Center for Nanoscience and Technology, Beijing 100190, China. E-mail: ding@nanoctr.cn

${ }^{c}$ Department of Chemistry, University of North Carolina at Chapel Hill, NC 27599, USA. E-mail: wyou@unc.edu

$\dagger$ Electronic supplementary information (ESI) available: Materials preparation and characterization, solar cells fabrication and measurements. See DOI: 10.1039/ c8qm00004b

\$ T. Li and H. Zhang contributed equally to this work.
}

in semi-transparent solar cells, ${ }^{7}$ tandem solar cells, ${ }^{8}$ and photodetectors. ${ }^{9}$ Therefore, developing new low-bandgap CO-bridged A-D-A acceptors is quite necessary. Here, we report the preparation of a hexacyclic CO-bridged ladder-type building block, $\mathrm{CO}_{\mathrm{i}} 6$, and the use of $\mathrm{CO}_{\mathrm{i}} 6$ in making three low-bandgap A-D-A acceptors, $\mathrm{CO}_{\mathrm{i}} 6 \mathrm{IC}, \mathrm{CO}_{\mathrm{i}} 6 \mathrm{FIC}$ and $\mathrm{CO}_{\mathrm{i}} 6 \mathrm{DFIC}$ (Fig. 1). The optical, electrochemical properties and the photovoltaic performance of $\mathrm{CO}_{\mathrm{i}} 6$-based acceptors were investigated. Fluorinesubstitution in the end units significantly affects the performance of the acceptors. Solar cells based on $\mathrm{CO}_{\mathrm{i}} 6 \mathrm{FIC}$ and a wide-bandgap copolymer donor, poly(4-(5-(4,8-bis(3-butylnonyl)benzo[1,2- $b$ :4,5$b^{\prime}$ ]dithiophen-2-yl)thiophen-2-yl)-2-(2-butyloctyl)-5,6-difluoro-7(thiophen-2-yl)-2H-benzo[d][1,2,3]triazole) (FTAZ), ${ }^{10}$ gave a PCE of $9.12 \%$.

The synthetic route is shown in Scheme 1. Stille coupling of (3,6-dimethoxythieno[3,2- $b]$ thiophene-2,5-diyl)bis(trimethylstannane) and 2-ethylhexyl 2-bromothiophene-3-carboxylate gave compound 1 in $83 \%$ yield. Treating compound 1 with $\mathrm{BBr}_{3}$ afforded the demethylated compound 2 in $95 \%$ yield. Compound 2 was quantitatively converted to bislactone 3 vi $a$ an acid-promoted intramolecular transesterification. ${ }^{6 b}$ The addition of four equivalents of Grignard reagent to $\mathbf{3}$ followed by an intramolecular dehydration cyclization afforded $\mathrm{CO}_{\mathrm{i}} 6$ in $86 \%$ yield. " ${ }^{11}$ "i" indicates that $\mathrm{C}-\mathrm{O}$ bonds point to the core of the molecule (inward), and " 6 " stands for six fused rings. Deprotonation of $\mathrm{CO}_{\mathrm{i}} 6$ by BuLi followed by adding $\mathrm{N}, \mathrm{N}$-dimethylformamide (DMF) produced $\mathrm{CO}_{\mathrm{i}} 6-\mathrm{CHO}$ in $80 \%$ yield. Finally, Knoevenagel condensation of $\mathrm{CO}_{\mathrm{i}} 6-\mathrm{CHO}$ with 1,1-dicyanomethylene-3-indanone (IC), monofluoro-substituted IC (FIC) or difluoro-substituted IC (DFIC) afforded $\mathrm{CO}_{\mathrm{i}}$ 6IC, $\mathrm{CO}_{\mathrm{i}} 6 \mathrm{FIC}$ and $\mathrm{CO}_{\mathrm{i}} 6 \mathrm{DFIC}$ in $90 \%, 94 \%$ and $86 \%$ yields, respectively. The structures of the compounds were confirmed by nuclear magnetic resonance (NMR) and mass spectroscopy (see ESI $\dagger$ ). These compounds show good solubility in common solvents such as chloroform, toluene and chlorobenzene. 


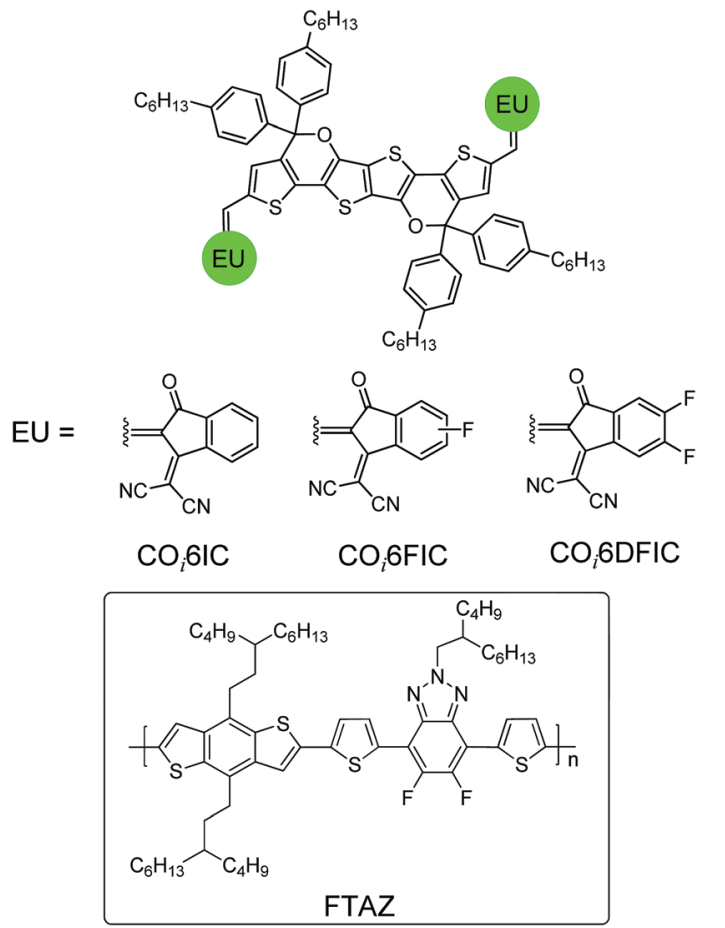

Fig. 1 The structures of $\mathrm{CO}_{i} 6 \mathrm{IC}, \mathrm{CO}_{i} 6 \mathrm{FIC}, \mathrm{CO}_{i} 6 \mathrm{DFIC}$ and FTAZ.
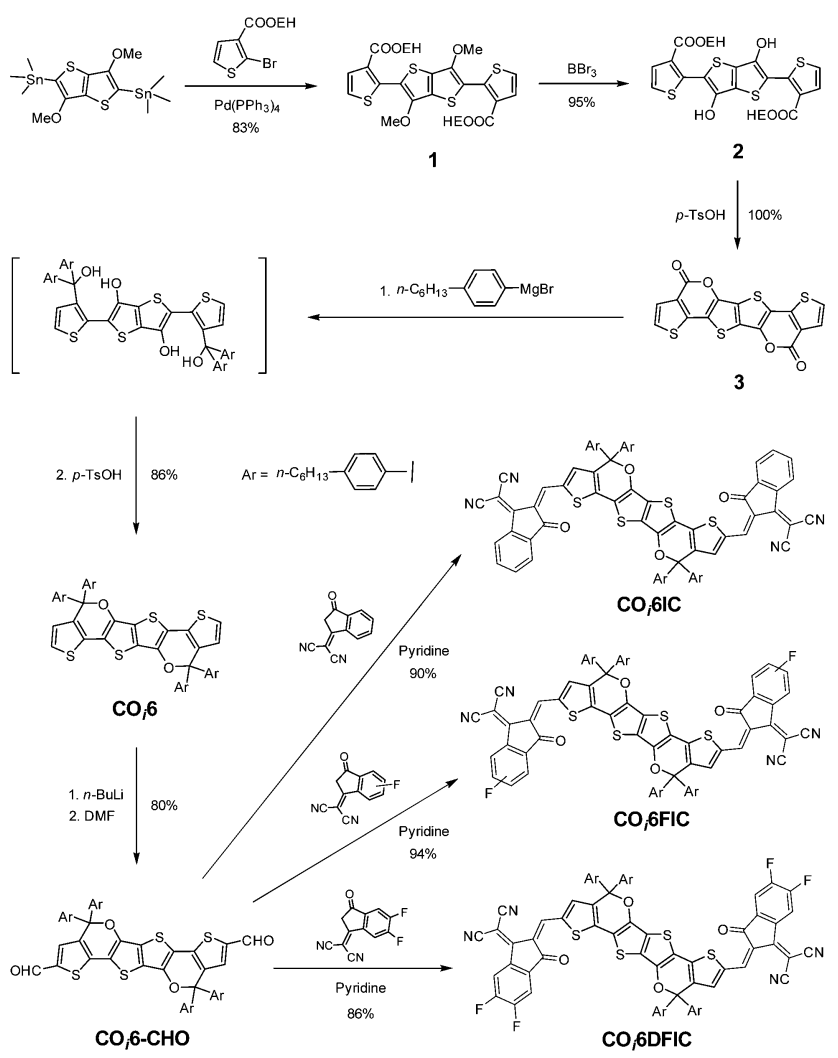

Scheme 1 The synthetic routes for $\mathrm{CO}_{i} 6 \mathrm{IC}, \mathrm{CO}_{i} 6 \mathrm{FIC}$ and $\mathrm{CO}_{i} 6 \mathrm{DFIC}$.

The absorption spectra for $\mathrm{CO}_{\mathrm{i}} 6 \mathrm{IC}, \mathrm{CO}_{\mathrm{i}} 6 \mathrm{FIC}, \mathrm{CO}_{\mathrm{i}} 6 \mathrm{DFIC}$ and FTAZ in chloroform and as films are shown in Fig. S15 (ESI $\dagger$ ) and Fig. 2, respectively. In solution, $\mathrm{CO}_{\mathrm{i}} 6 \mathrm{IC}, \mathrm{CO}_{\mathrm{i}} 6 \mathrm{FIC}$ and

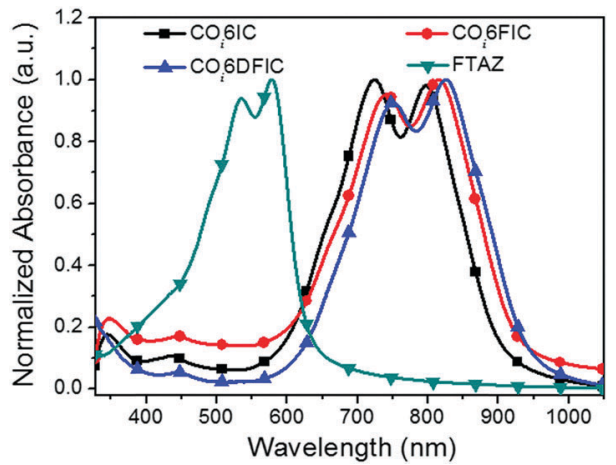

Fig. 2 Absorption spectra for $\mathrm{CO}_{i} 6 \mathrm{IC}, \mathrm{CO}_{i} 6 \mathrm{FIC}, \mathrm{CO}_{i} 6 \mathrm{DFIC}$ and FTAZ films.

CO $_{\text {i }}$ DFIC show a strong intramolecular charge transfer (ICT) band at 600-850 nm, with a low-energy peak at $755 \mathrm{~nm}, 764 \mathrm{~nm}$ and $769 \mathrm{~nm}$, respectively, and a shoulder absorption at $697 \mathrm{~nm}$, $701 \mathrm{~nm}$ and $702 \mathrm{~nm}$, respectively (Table 1). For films, the absorption show bathochromic shifts and the shoulder absorption intensifies. From solution to film, the redshifts for the low-energy peaks of $\mathrm{CO}_{\mathrm{i}} 6 \mathrm{IC}, \mathrm{CO}_{\mathrm{i}} 6 \mathrm{FIC}$ and $\mathrm{CO}_{\mathrm{i}} 6 \mathrm{DFIC}$ are $40 \mathrm{~nm}$, $51 \mathrm{~nm}$ and $55 \mathrm{~nm}$, respectively, suggesting that the fluorination on IC unit enhanced the intermolecular interaction. The optical bandgaps $\left(E_{\mathrm{g}}^{\mathrm{opt}}\right)$ estimated from the absorption onsets of $\mathrm{CO}_{\mathrm{i}} 6 \mathrm{IC}$, $\mathrm{CO}_{\mathrm{i}} 6 \mathrm{FIC}$ and CO${ }_{\mathrm{i}} 6 \mathrm{DFIC}$ films are $1.37 \mathrm{eV}, 1.34 \mathrm{eV}$ and $1.31 \mathrm{eV}$, respectively. Small $E_{\mathrm{g}}^{\text {opt }}$ suggests strong electron-donating capability of $\mathrm{CO}_{\mathrm{i}} 6$ unit. $^{12}$ Fluorine atoms enhance electron-withdrawing capability of the end units and strengthen the ICT, leading to a bandgap shrink. FTAZ film absorbs 350-650 nm light, which is complementary to $\mathrm{CO}_{\mathrm{i}} 6$ acceptors $(600-950 \mathrm{~nm})$. The energy levels estimated from CV measurements are shown in Fig. $3 .^{13}$ The highest occupied molecular orbital (HOMO) levels for $\mathrm{CO}_{\mathrm{i}} 6 \mathrm{IC}$, $\mathrm{CO}_{\mathrm{i}}$ 6FIC and $\mathrm{CO}_{\mathrm{i}}$ 6DFIC are $-5.57 \mathrm{eV},-5.60 \mathrm{eV}$ and $-5.64 \mathrm{eV}$, respectively, and the lowest unoccupied molecular orbital (LUMO) levels are $-3.86 \mathrm{eV},-3.93 \mathrm{eV}$ and $-4.04 \mathrm{eV}$, respectively. Fluorine atoms lower both HOMO and LUMO levels, but they lower LUMO more. The donor FTAZ exhibits a HOMO at $-5.36 \mathrm{eV}$ and a LUMO at $-3.05 \mathrm{eV}$.

Bulk heterojunction solar cells with a structure of ITO/ZnO/ FTAZ:acceptor $/ \mathrm{MoO}_{3} / \mathrm{Ag}$ were fabricated to evaluate the performance of $\mathrm{CO}_{\mathrm{i}} 6$ acceptors. ${ }^{14}$ The optimized conditions for FTAZ:CO 6 6IC, FTAZ:CO ${ }_{\mathrm{i}} 6 \mathrm{FIC}$ and FTAZ:CO $\mathrm{C}_{\mathrm{i}}$ DDFIC solar cells are the same: a D/A ratio of $1: 1.6(\mathrm{w} / \mathrm{w})$, an active layer thickness of $\sim 85 \mathrm{~nm}$ and 0.2 vol\% 1,8-diiodooctane (DIO) as the additive (Tables S1-S9, ESI $\dagger$ ). $J-V$ curves and external quantum efficiency (EQE) spectra for the best cells are shown in Fig. 4, and the performance data are listed in Table 2. Fluorine substitution can significantly affect the performance of $\mathrm{CO}_{\mathrm{i}} 6$ acceptors. The open-circuit voltages $\left(V_{\text {oc }}\right)$ for $\mathrm{CO}_{\mathrm{i}} 6 \mathrm{IC}, \mathrm{CO}_{\mathrm{i}} 6 \mathrm{FIC}$ and $\mathrm{CO}_{\mathrm{i}} 6 \mathrm{DFIC}$ cells are $0.82 \mathrm{~V}, 0.75 \mathrm{~V}$ and $0.67 \mathrm{~V}$, respectively. $V_{\text {oc }}$ decreasing along with fluorine substitution is due to LUMO descending, since $V_{\mathrm{oc}}$ is proportional to $\left(\mathrm{LUMO}_{\text {acceptor }}-\mathrm{HOMO}_{\text {donor }}\right){ }^{15}$ In contrast, the short-circuit current densities $\left(J_{\mathrm{sc}}\right)$ increase along with fluorine substitution. $J_{\mathrm{sc}}$ of $17.45 \mathrm{~mA} \mathrm{~cm}{ }^{-2}, 19.38 \mathrm{~mA} \mathrm{~cm}^{-2}$ and $20.98 \mathrm{~mA} \mathrm{~cm}^{-2}$ were obtained from $\mathrm{CO}_{\mathrm{i}} 6 \mathrm{IC}, \mathrm{CO}_{\mathrm{i}} 6 \mathrm{FIC}$ and $\mathrm{CO}_{\mathrm{i}} 6 \mathrm{DFIC}$ cells, respectively. With fluorine substitution, 
Table 1 Optical and electrochemical data for the acceptors

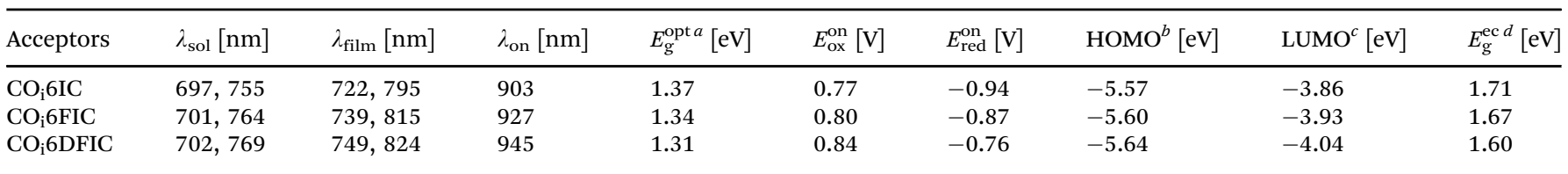

${ }^{a} E_{\mathrm{g}}^{\mathrm{opt}}=1240 / \lambda_{\mathrm{on}} \cdot{ }^{b} \mathrm{HOMO}=-\left(E_{\mathrm{Ox}}^{\mathrm{on}}+4.8\right) \cdot{ }^{c}$ LUMO $=-\left(E_{\mathrm{red}}^{\mathrm{on}}+4.8\right) \cdot{ }^{d} E_{\mathrm{g}}^{\mathrm{ec}}=$ LUMO - HOMO.

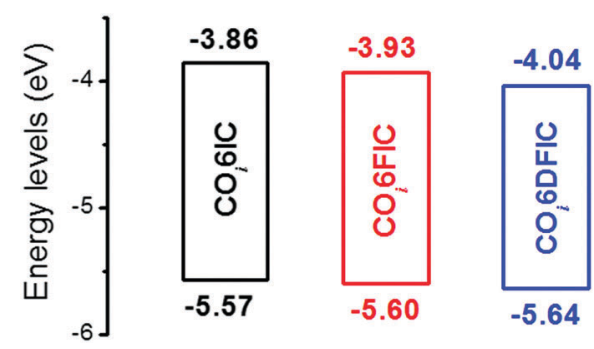

Fig. 3 Energy level diagram.

(a)

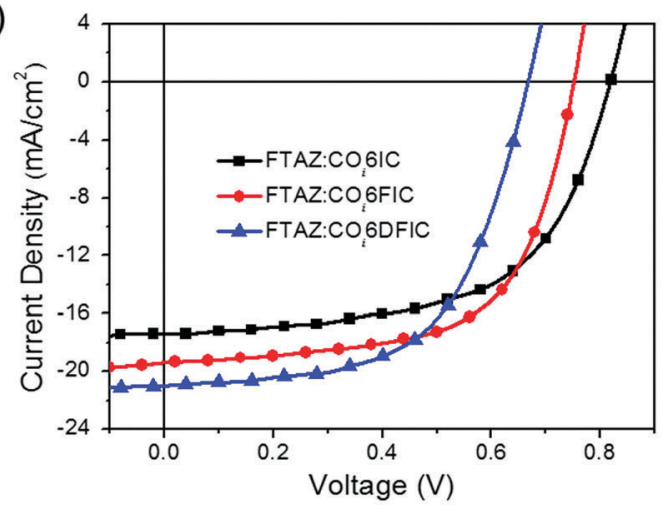

(b)

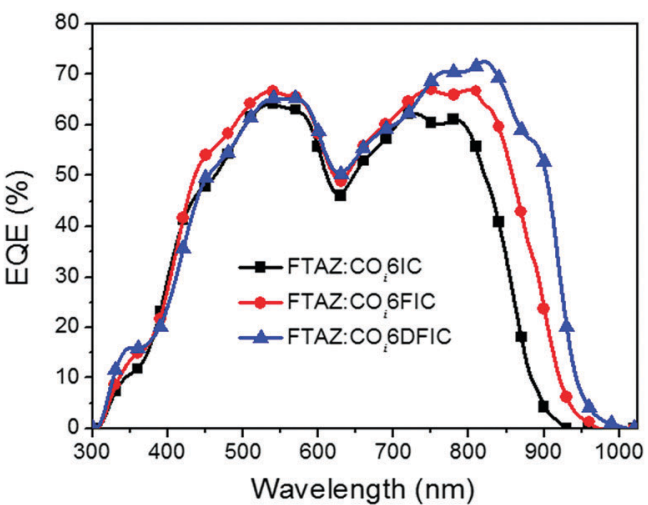

Fig. $4 J-V$ curves (a) and EQE spectra (b) for the solar cells.

the EQE spectra broaden and intensify (Fig. 4b). The broadening of EQE spectra results from the enhanced lightharvesting capability of the acceptors, while enhanced EQE might result from the improved charge generation and transport in the active layer. The integrated photocurrent densities from EQE spectra are consistent with $J_{\mathrm{sc}}$ from $J-V$ measurements (Table 2). The fill factors (FF) for $\mathrm{CO}_{\mathrm{i}} 6 \mathrm{IC}, \mathrm{CO}_{\mathrm{i}} 6 \mathrm{FIC}$ and $\mathrm{CO}_{\mathrm{i}}$ 6DFIC cells are $59.0 \%, 62.6 \%$ and $58.9 \%$, respectively. $\mathrm{CO}_{\mathrm{i}}$ 6FIC solar cells gave the highest PCE of $9.12 \%$.
Table 2 Performance data for the solar cells

\begin{tabular}{lllll}
\hline D:A & $V_{\text {oc }}[\mathrm{V}]$ & $J_{\text {sc }}\left[\mathrm{mA} \mathrm{cm}^{-2}\right]$ & FF $[\%]$ & PCE [\%] \\
\hline FTAZ:CO 6 6IC & 0.82 & $17.45(16.93)^{a}$ & 59.0 & $8.43(8.35)^{b}$ \\
FTAZ:CO 6 6FIC & 0.75 & $19.38(19.27)$ & 62.6 & $9.12(9.02)$ \\
FTAZ:CO 6 6DFIC & 0.67 & $20.98(20.39)$ & 58.9 & $8.25(8.11)$
\end{tabular}

${ }^{a}$ The data in the parentheses are integrated current density from EQE spectra. ${ }^{b}$ The data in the parentheses are averages for 10 cells.

To understand the fluorination effect on the photovoltaic performance of $\mathrm{CO}_{\mathrm{i}} 6$ acceptors, we first studied the exciton dissociation probabilities $\left(P_{\text {diss }}\right)$ in different cells (Fig. 5a). ${ }^{16} P_{\text {diss }}$ for $\mathrm{CO}_{\mathrm{i}} 6 \mathrm{IC}, \mathrm{CO}_{\mathrm{i}} 6 \mathrm{FIC}$ and $\mathrm{CO}_{\mathrm{i}} 6 \mathrm{DFIC}$ cells are $90.4 \%, 94.1 \%$ and $93.9 \%$, respectively. Higher $P_{\text {diss }}$ for $\mathrm{CO}_{\mathrm{i}} 6 \mathrm{FIC}$ and $\mathrm{CO}_{\mathrm{i}} 6 \mathrm{DFIC}$ cells indicate that fluorination favors the generation of free charge carriers. This explains the higher EQE and $J_{\mathrm{sc}}$ of $\mathrm{CO}_{\mathrm{i}} 6 \mathrm{FIC}$ and $\mathrm{CO}_{\mathrm{i}} 6 \mathrm{DFIC}$ cells than that of $\mathrm{CO}_{\mathrm{i}} 6 \mathrm{IC}$ cells. We studied bimolecular recombination by plotting $J_{\text {sc }}$ against light intensity $\left(P_{\text {light }}\right)$ (Fig. $\left.5 \mathrm{~b}\right) .{ }^{17}$ The data were fitted to a power law: $J_{\text {sc }} \propto P_{\text {light }}^{\alpha}$. The $\alpha$ values for $\mathrm{CO}_{\mathrm{i}} 6 \mathrm{IC}, \mathrm{CO}_{\mathrm{i}} 6 \mathrm{FIC}$ and $\mathrm{CO}_{\mathrm{i}}$ 6DFIC cells are $0.978,0.987$ and 0.983 ,

(a)

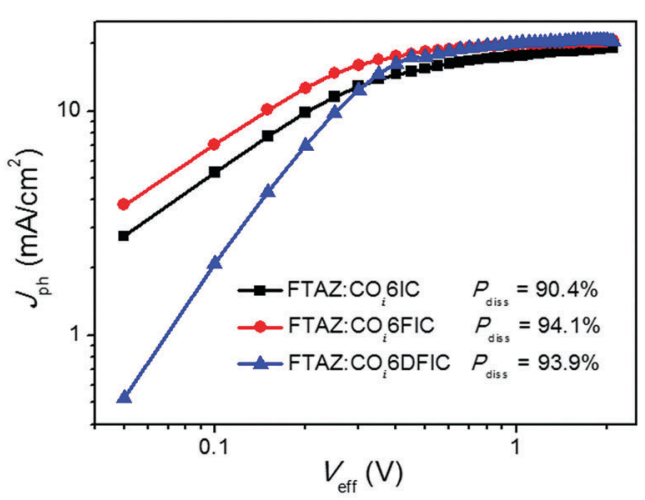

(b)

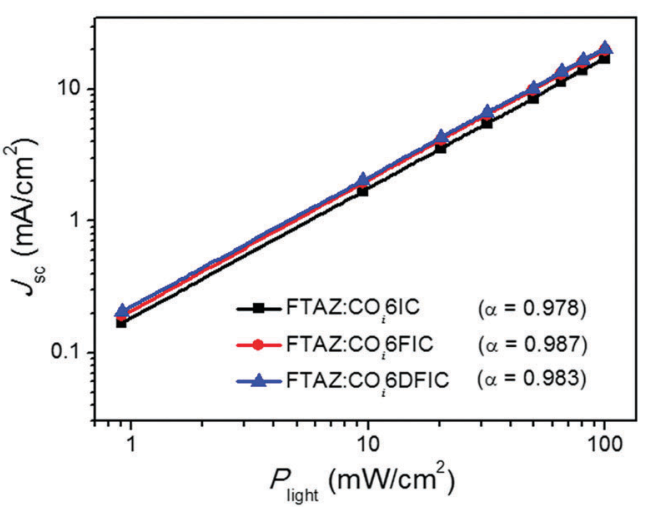

Fig. 5 (a) $J_{\text {ph }}-V_{\text {eff }}$ plots; (b) $J_{\text {sc }}-P_{\text {light }}$ plots. 
respectively, suggesting that solar cells using fluorinated acceptors have less charge recombination. Charge carrier mobilities were evaluated by using space charge limited current (SCLC) method (Fig. S17 and S18, ESI $\dagger$ ) ${ }^{18}$ Compared with FTAZ:CO 6 6IC blend film, the hole and electron mobilities $\left(\mu_{\mathrm{h}}\right.$ and $\left.\mu_{\mathrm{e}}\right)$ simultaneously got improved in FTAZ:CO $\mathrm{CO}_{\mathrm{i}}$ FIC and FTAZ:CO $\mathrm{CO}_{\mathrm{i}}$ 6DFIC blend films (Table S10, ESI $\dagger$ ). FTAZ:CO 6 6FC film shows the highest $\mu_{\mathrm{h}}$ and $\mu_{\mathrm{e}}$ of $1.45 \times 10^{-4} \mathrm{~cm}^{2} \mathrm{~V}^{-1} \mathrm{~s}^{-1}$ and $2.07 \times 10^{-5} \mathrm{~cm}^{2} \mathrm{~V}^{-1} \mathrm{~s}^{-1}$, respectively. FTAZ: $\mathrm{CO}_{\mathrm{i}} 6 \mathrm{FIC}$ film presents the most balanced charge carrier transport, thus delivering the highest FF.

Film morphology was studied by using atomic force microscope (AFM) (Fig. S19, ESI $\dagger$ ). FTAZ:CO ${ }_{\mathrm{i}} 6 \mathrm{FIC}$ blend film gives the smoothest surface among the three films. The root-mean-square roughnesses for FTAZ:CO 6 6IC, FTAZ:CO 6 6FIC and FTAZ:CO 6 6DFC films are $2.33 \mathrm{~nm}, 0.94 \mathrm{~nm}$ and $1.87 \mathrm{~nm}$, respectively. FTAZ:CO 6 FIC blend film presents the finest nanofibers with diameters around $12 \mathrm{~nm}$. With appropriate fluorination at the end units of the acceptor, the donor and acceptor materials can present a suitable miscibility and can make ideal nanoscale phase separation for efficient charge generation and transport, thus delivering optimal photovoltaic performance.

\section{Conclusions}

In summary, a CO-bridged hexacyclic core unit $\left(\mathrm{CO}_{\mathrm{i}} 6\right)$ and three A-D-A nonfullerene acceptors were developed. Owing to the strong electron-donating capability of $\mathrm{CO}_{\mathrm{i}} 6$, these acceptors present narrow optical bandgaps and good NIR absorption. The energy levels, light absorption, mobilities, and the miscibility between donor and acceptor materials can be tuned vi $a$ fluorination. Solar cells based on a wide-bandgap polymer donor (FTAZ) and $\mathrm{CO}_{\mathrm{i}} 6$ acceptors gave decent PCEs, and FTAZ:CO 6 6FIC cells delivered the highest PCE of $9.12 \%$. This work also demonstrates the great potential of CO-bridged low-bandgap nonfullerene acceptors.

\section{Conflicts of interest}

There are no conflicts to declare.

\section{Acknowledgements}

We greatly appreciate National Natural Science Foundation of China (U1401244, 21374025, 21372053, 21572041, 51503050, 51773045, 21772030 and 21704021), National Key Research and Development Program of China (2017YFA0206600) and the Youth Association for Promoting Innovation (CAS) for financial support. H. Niu thanks National Natural Science Foundation of China (51771001, 21471001 and 21575001) and Natural Science Foundation of Anhui Province (1508085MB3) for financial support.

\section{References}

1 (a) Y. Lin and X. Zhan, Mater. Horiz., 2014, 1, 470; (b) W. Chen and Q. Zhang, J. Mater. Chem. C, 2017, 5, 1275; (c) S. Li, Z. Zhang, M. Shi, C.-Z. Li and H. Chen, Phys. Chem. Chem. Phys., 2017, 19, 3440.

2 Y. Lin, J. Wang, Z. G. Zhang, H. Bai, Y. Li, D. Zhu and X. Zhan, Adv. Mater., 2015, 27, 1170.

3 Y. Lin, F. Zhao, Y. Wu, K. Chen, Y. Xia, G. Li, S. K. K. Prasad, J. Zhu, L. Huo, H. Bin, Z. G. Zhang, X. Guo, M. Zhang, Y. Sun, F. Gao, Z. Wei, W. Ma, C. Wang, J. Hodgkiss, Z. Bo, O. Inganäs, Y. Li and X. Zhan, Adv. Mater., 2017, 29, 1604155. 4 Z. Xiao, X. Jia and L. Ding, Sci. Bull., 2017, 62, 1562.

5 (a) J. Wang, W. Wang, X. Wang, Y. Wu, Q. Zhang, C. Yan, W. Ma, W. You and X. Zhan, Adv. Mater., 2017, 29, 1702125; (b) S. Dai, F. Zhao, Q. Zhang, T.-K. Lau, T. Li, K. Liu, Q. Ling, C. Wang, X. Lu, W. You and X. Zhan, J. Am. Chem. Soc., 2017, 139, 1336; (c) Y. Lin, F. Zhao, Q. He, L. Huo, Y. Wu, T. C. Parker, W. Ma, Y. Sun, C. Wang, D. Zhu, A. J. Heeger, S. R. Marder and X. Zhan, J. Am. Chem. Soc., 2016, 138, 4955. 6 (a) Z. Xiao, F. Liu, X. Geng, J. Zhang, S. Wang, Y. Xie, Z. Li, H. Yang, Y. Yuan and L. Ding, Sci. Bull., 2017, 62, 1331; (b) Z. Xiao, X. Jia, D. Li, S. Wang, X. Geng, F. Liu, J. Chen, S. Yang, T. P. Russell and L. Ding, Sci. Bull., 2017, 62, 1494.

7 (a) W. Wang, C. Yan, T.-K. Lau, J. Wang, K. Liu, Y. Fan, X. Lu and X. Zhan, Adv. Mater., 2017, 29, 1701308; (b) F. Liu, Z. Zhou, C. Zhang, J. Zhang, Q. Hu, T. Vergote, F. Liu, T. P. Russell and X. Zhu, Adv. Mater., 2017, 29, 1606574.

8 W. Liu, S. Li, J. Huang, S. Yang, J. Chen, L. Zuo, M. Shi, X. Zhan, C.-Z. Li and H. Chen, Adv. Mater., 2016, 28, 9729.

9 W. Wang, F. Zhang, H. Bai, L. Li, M. Gao, M. Zhang and X. Zhan, Nanoscale, 2016, 8, 5578.

10 S. C. Price, A. C. Stuart, L. Yang, H. Zhou and W. You, J. Am. Chem. Soc., 2011, 133, 4625.

11 L. Dou, C.-C. Chen, K. Yoshimura, K. Ohya, W.-H. Chang, J. Gao, Y. Liu, E. Richard and Y. Yang, Macromolecules, 2013, 46, 3384.

12 H. Zhou, L. Yang and W. You, Macromolecules, 2012, 45, 607. 13 Z. Xiao, G. Ye, Y. Liu, S. Chen, Q. Peng, Q. Zuo and L. Ding, Angew. Chem., Int. Ed., 2012, 51, 9038.

14 Z. Xiao, X. Geng, D. He, X. Jia and L. Ding, Energy Environ. Sci., 2016, 9, 2114.

15 B. P. Rand, D. P. Burk and S. R. Forrest, Phys. Rev. B: Condens. Matter Mater. Phys., 2007, 75, 115327.

16 J.-L. Wu, F.-C. Chen, Y.-S. Hsiao, F.-C. Chien, P. Chen, C.-H. Kuo, M. H. Huang and C.-S. Hsu, ACS Nano, 2011, 5, 959.

17 M. An, F. Xie, X. Geng, J. Zhang, J. Jiang, Z. Lei, D. He, Z. Xiao and L. Ding, Adv. Energy Mater., 2017, 7, 1602509.

18 J. Cao, Q. Liao, X. Du, J. Chen, Z. Xiao, Q. Zuo and L. Ding, Energy Environ. Sci., 2013, 6, 3224. 